\title{
INFLUENCE OF VARIETY, GROWTH LOCATION AND STORAGE CONDITIONS ON DEVELOPMENT OF HARD-TO-COOK DEFECT IN COMMON BEAN (Phaseolus vulgaris. L)
}

\author{
J Balamaze $^{1}$, JH Muyonga ${ }^{\text {* }}$,WM Kyamuhangire ${ }^{1}$, JK Kikafunda ${ }^{1}$, \\ D Nakimbugwe ${ }^{1}$ and $M$ Ugen $^{2}$
}

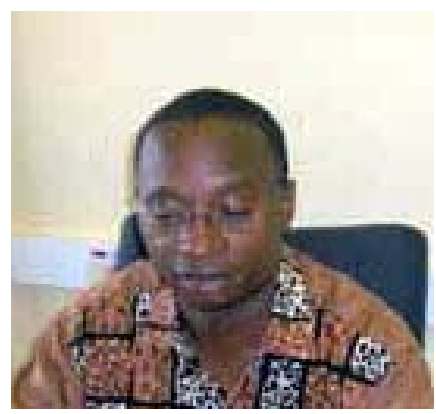

John Muyonga

*Corresponding author email: hmuyonga@yahoo.com

${ }^{1}$ Department of Food Science and Technology, Makerere University Kampala Uganda.

${ }^{2}$ Namulonge Agricultural and Animal Research Institute

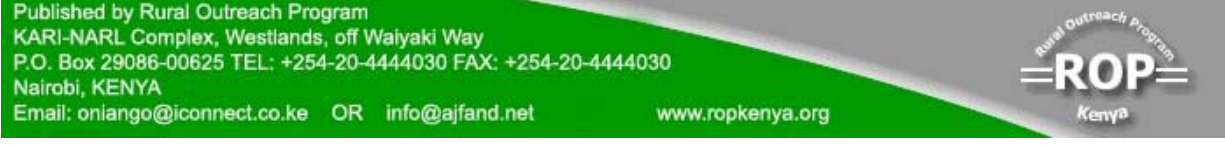




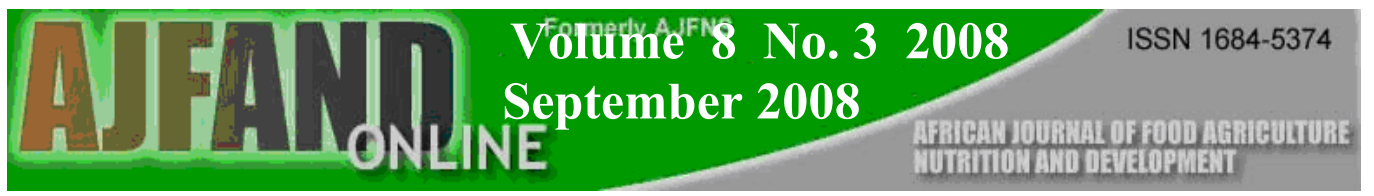

\begin{abstract}
Storage of beans, especially at temperatures higher than $25^{\circ} \mathrm{C}$, and relative humidity greater than $65 \%$, lead to development of the hard-to-cook (HTC) defect which results in increased cooking time, fuel and water use. This has a negative effect on acceptability and utilization of beans. This study was aimed at investigating the influence of bean variety, moisture content, growth location and storage containers on the development of HTC defect. Freshly harvested (within one month of storage) beans of varieties K131, K132, NABE4 and NABE 11 collected from farmers were first assessed for susceptibility to the HTC defect and then chemical changes associated with differences in moisture content and storage conditions were determined. Bean samples were obtained from farmers at initial moisture content of about $15 \%$. Some of the beans were dried to moisture content of 12 and $9 \%$. Samples at $15 \%, 12 \%$ and $9 \%$ were stored in plastic buckets, earthenware, polypropylene and sisal bags at ambient temperature $\left(22-28{ }^{\circ} \mathrm{C}\right)$. Samples were drawn at monthly intervals and analyzed for cooking time, lignin, acid detergent fiber, calcium and magnesium content. Extent of HTC defect was found to be in the order K131> K132> NABE11> NABE4. The higher the moisture content the greater the extent of HTC development. HTC was found to be associated with increase in lignin content $\left(\mathrm{r}^{2}=\right.$ 0.72). A significant increase in acid detergent fibre (ADF) was observed in samples stored in all the 4 storage containers. The increase was highest for beans stored in polypropylene bags and plastic buckets while beans stored in the sisal bags and earthenware had the least increase. Storage in sisal bags $\left(25^{\circ} \mathrm{C}, \mathrm{RH} 74 \%\right)$ which allowed equilibration of the temperature and relative humidity with that of the environment controlled HTC defect development more than other methods; pot $\left(22^{\circ} \mathrm{C}\right.$, $\mathrm{RH} 93 \%)$ polypropylene bags $\left(25.8^{\circ} \mathrm{C}, \mathrm{RH} 80 \%\right)$ and plastic bucket $\left(27.9^{\circ} \mathrm{C}, \mathrm{RH}\right.$ $84 \%$ ). Based on the results of this study drying beans to lower moisture content and prevention of heat build up during storage, are recommended as strategies to control HTC development.
\end{abstract}

Key words: Hard -to-cook, Legumes, Grain storage, Lignification. 


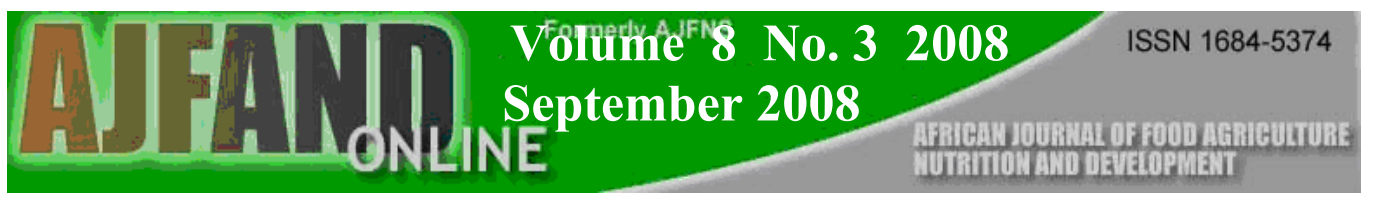

\section{INTRODUCTION}

The common bean (Phaseolus vulgaris) is an important legume food crop and constitutes an essential part of the diet for over 700 million people in the world [1]. It is the most widely produced legume in Africa and is grown almost exclusively by poor farmers [2]. In Uganda, beans are among the most important crops in the agricultural sector and household economy [3]. Currently, the annual beans production in Uganda is estimated at 545,000 metric tonnes valued at \$2.5 million [4]. About $6 \%$ of the beans produced in Uganda annually are wasted due to pre-harvest environmental conditions and poor post harvest handling conditions [1]. Bean wastage is mainly caused by weevils and HTC defect. HTC development is associated with storage of beans under conditions of high temperature $\left(\geq 25^{\circ} \mathrm{C}\right)$ and high relative humidity $(\geq 65 \%)$ [5]. Several containers are used to store beans and these include sisal or polypropylene bags, metal or plastic containers, cribs and baskets. Some of these containers may result in temperature or moisture build up, leading to development of HTC defect. Cooking beans which have developed the defect takes several hours to prepare and requires large amounts of water and fuel [5]. Over 15 bean varieties have been developed in Uganda over the last 35 years. The focus in development of new varieties has been high yield, pest and drought resistant. There has, however, been limited focus on the varietal susceptibility to the HTC defect, a major factor with respect to acceptability.

In this study, susceptibility of 4 common bean varieties grown in Uganda to HTC defect as well as the effect of growth areas and storage conditions were investigated.

\section{MATERIALS AND METHODS}

\section{Samples}

Freshly harvested samples of K131, K132, NABE4 and NABE11 varieties were collected from Kabale and Lira districts of Uganda. Variety K131 has the highest average yield estimated at $2,500 \mathrm{~kg} / \mathrm{ha}$ under recommended agronomic conditions compared to less than $1,600 \mathrm{~kg} / \mathrm{ha}$ for other varieties [6]. Variety $\mathrm{K} 131$ has an average seed length of about 3-4 mm compared to 7-9 $\mathrm{mm}$ for other varieties. Varieties K132 and NABE4 are both red mottled with seed size bigger than that of K131. Variety NABE11 has the biggest seed size among all the four varieties. It yields slightly more than K132 and NABE4 and it is yellowish with brown strips. Kabale District is located in the highland areas of western Uganda with a temperature range of $10-17^{\circ} \mathrm{C}$ and annual rain fall of $1,000-1480 \mathrm{~mm}$. Lira District is located in northern Uganda. It is a lowland district, with a temperatures range of $25-35^{\circ} \mathrm{C}$ and annual average rainfall of 1,200-2,000mm. Beans samples were also collected from Namulonge Animal and Agricultural Research Institute (NAARI) in the central region. This region has annual rainfall of about $1200 \mathrm{~mm}$ and average temperature of $28^{\circ} \mathrm{C}$.

\section{Accelerated hardening study of beans varieties}

Triplicates samples (20 grams) of each variety of beans obtained from farmers in Lira, Kabale and from NAARI and containing $15 \pm 0.5 \%$ moisture content were weighed

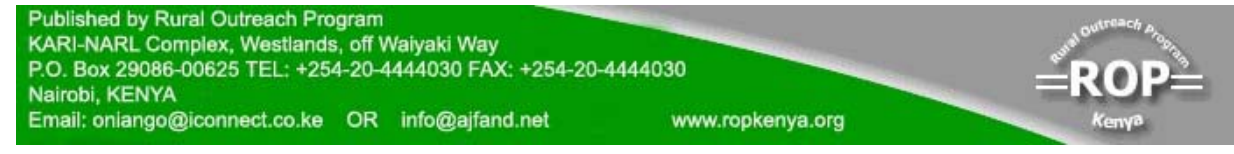


and soaked in $60 \mathrm{ml}$ of $0.1 \mathrm{M}$ acetate buffer $\mathrm{pH} 4.0$ for 1, 2, 3, 4 and 5 hours. The cooking time for six bean seeds randomly selected from the soaked beans was determined in triplicate using a Mattson bean cooker [7].

\section{Determination of the effect of moisture content and containers on development of HTC defect}

Freshly harvested beans of K131, K132, NABE4 and NABE11 obtained from farmers were sun dried to attain 2 different moisture levels ( $9 \%$ and 12\%). Drying the samples to required moisture level was achieved by getting the difference between the moisture level of the beans and the desired moisture level. The moisture loss required to obtain target moisture content was calculated and beans dried until the calculated mass was lost. The samples were sun dried while monitoring the change in the sample mass until the calculated mass loss was achieved. The moisture content of the samples was measured to ensure that it was at the target level. Samples containing about 9, 12, and $15 \%$ moisture were stored in earthen ware, plastic buckets polypropylene and sisal sacks. Bean samples were periodically drawn (at monthly intervals) and the cooking time determined using the Mattson Bean Cooker [7]. Acid detergent fibre and lignin content were determined gravimetrically in triplicates using AOAC procedure [8] method No. 973.18. The analysis for calcium and magnesium was done using Atomic Absorption Spectrometer at the beginning and end of the storage period using AOAC method [8] No. 968.08.

Statistical Analysis: All data presented are means of triplicate determination of cooking time, lignin and acid detergent fibre. Differences between varieties with respect to changes in cooking time, lignin and acid detergent fibre during storage were determined using two way analysis of variance. The least significant difference (LSD) at $5 \%$ probability level was used for mean separation. Correlation between the cooking time and other parameters was also carried out to determine the relationship between them.

\section{RESULTS}

\section{Accelerated hardening of bean varieties}

Bean varieties showed differences in rate of developing HTC defect during the accelerated hardening experiment (Figure 1). Varieties K131 and K132 were observed to be more prone to hardening (had higher cooking time) than NABE4 and NABE11 after 5 hours of soaking in the acetate buffer. 
Figure 1: Variation of cooking time with soaking duration of different bean varieties collected from different locations in Uganda

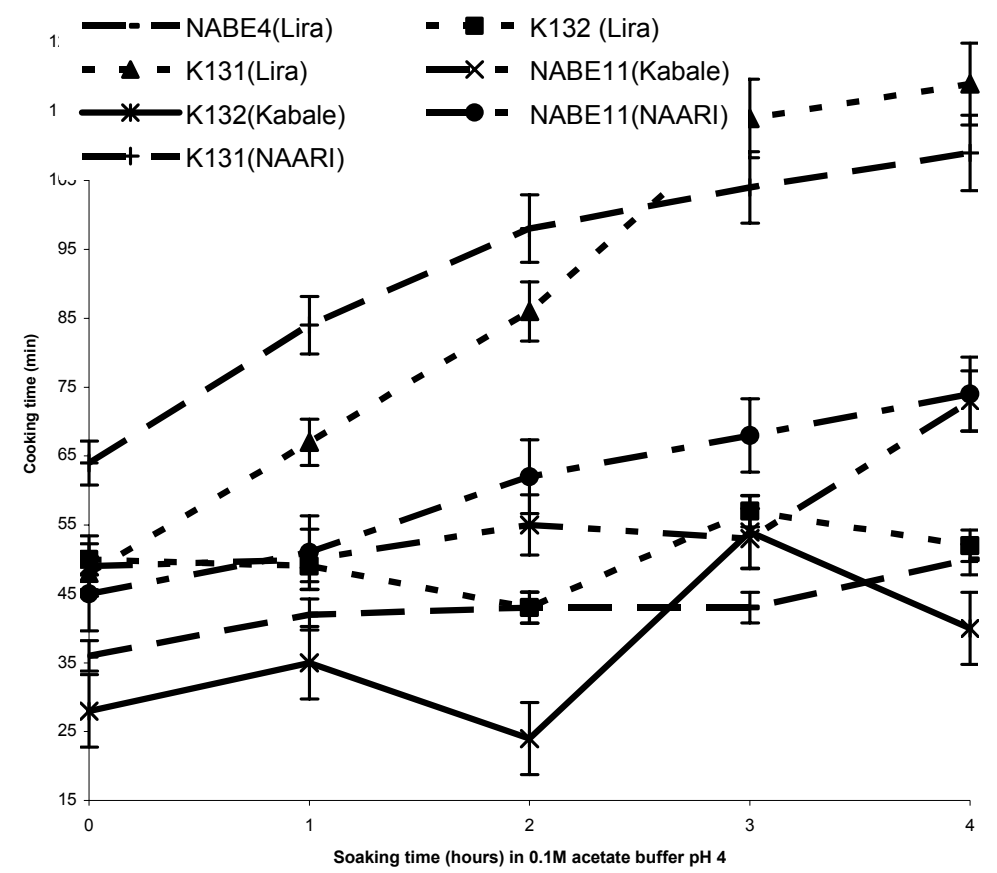

Samples of the same variety from different locations showed different cooking periods after soaking for the same period in the $\mathrm{pH} 4$ acetate buffer. The extent of development of HTC defect in beans obtained from different locations was related to calcium and magnesium content (Table $2 \mathrm{a}$ and $2 \mathrm{~b}$ ), with the samples containing high calcium and magnesium exhibiting higher increase in percentage hardening.

Influence of storage containers on HTC development

Variety K131 showed the highest increase in cooking time compared to other varieties during storage in the different containers (Figure 2). The extent of hardening was highest in the K131 and K132 beans stored in earthenware and plastic containers. 
Figure 2: Variation in the cooking time for the beans collected from Lira and stored in different containers. (a) Earthenware (b) Polypropylene bags (c) Plastic buckets (d) Sisal bags

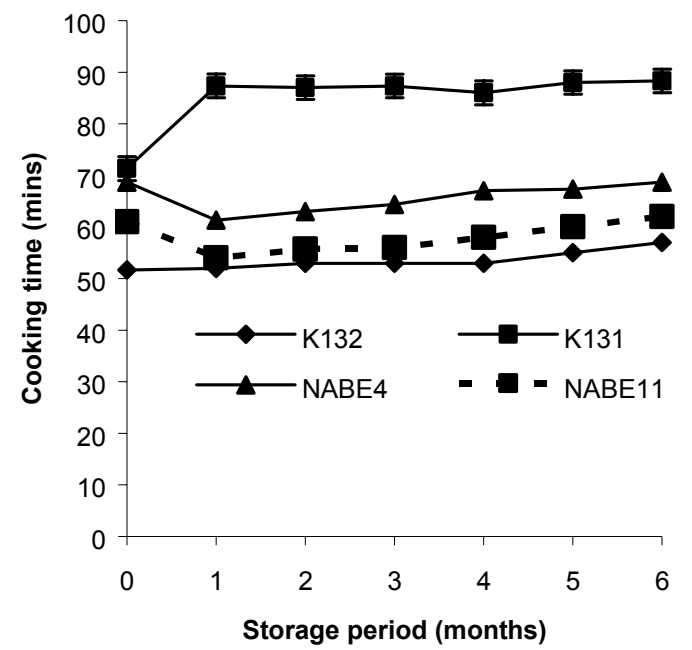

(a)

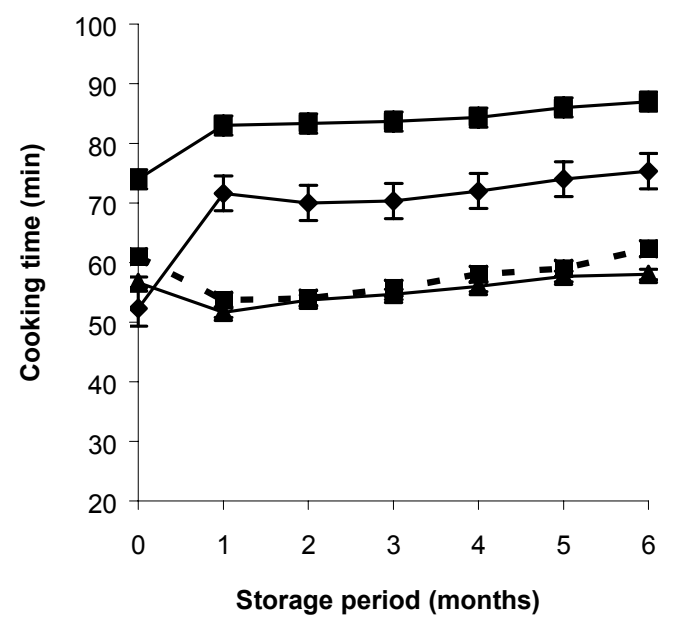

(c)

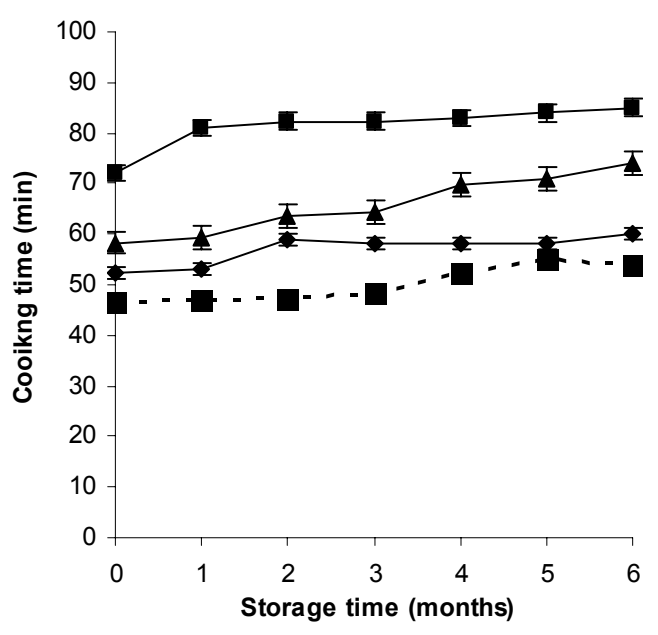

(b)

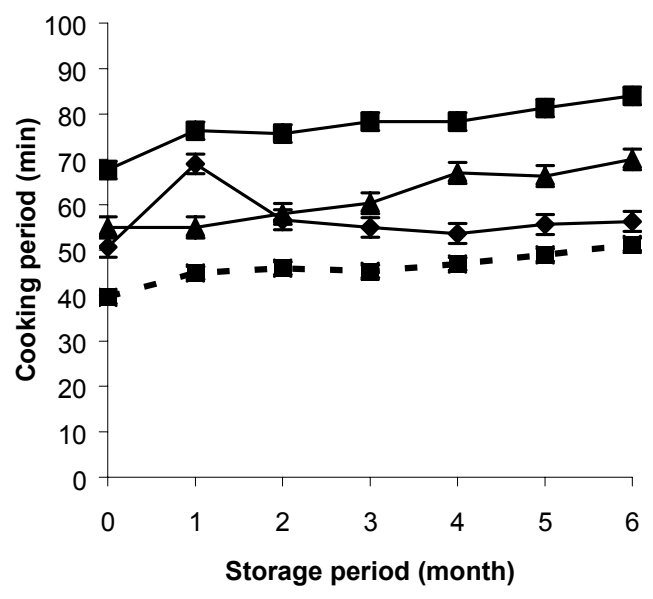

(d)

The lowest cooking time for these same varieties was observed in samples stored in sisal bags. Similar trends were observed in NABE4 and NABE 11 (Table 1). Beans stored in sisal bags, which controlled both the temperature and relative humidity build up, had the least change in cooking time. The cooking time for beans stored in the plastic buckets was higher than that for beans stored in the polypropylene bags. The 
average temperature in the polypropylene bags $\left(25.8^{0} \mathrm{C}\right)$ was slightly lower than that in the plastic buckets $\left(27.8^{\circ} \mathrm{C}\right)$. Variety $\mathrm{K} 131$ which was found to be more susceptible to HTC development during the accelerated hardening test had the longest cooking time under all the storage conditions studied.

\section{Chemical changes during storage}

The acid detergent fibre content for the four varieties after storage for 6 months was between 3.64 and $8.06 \%$ (Figure 3). This is in agreement with results (3-10\%) reported by Bressani [9]. A significant increase in ADF was observed in samples stored in all the 4 storage containers. The increase was highest for beans stored in polypropylene bags and plastic buckets while beans stored in the sisal bags and earthenware had the least increase. 
Figure 3: Changes in (acid detergent fibre) ADF with storage for the beans collected from Lira and in different containers. (a) Polypropylene bags, (b) earthenware, (c) plastic buckets, (d) sisal bags

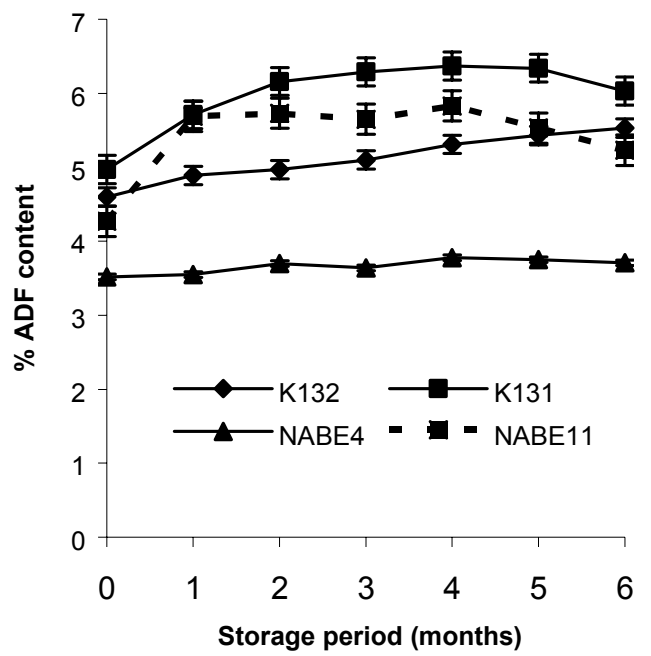

(a)

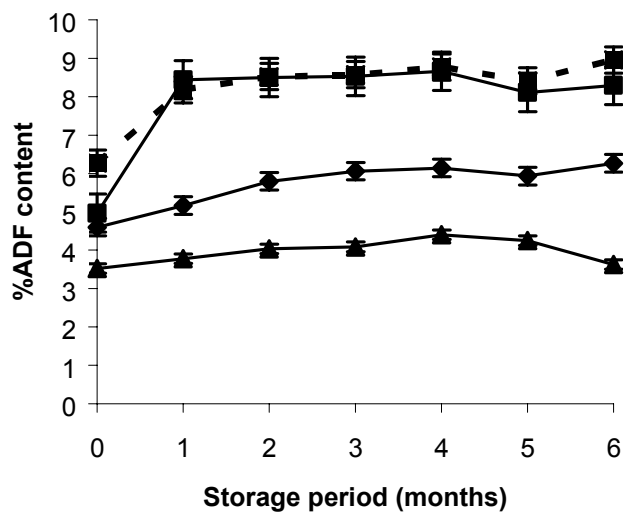

(c)

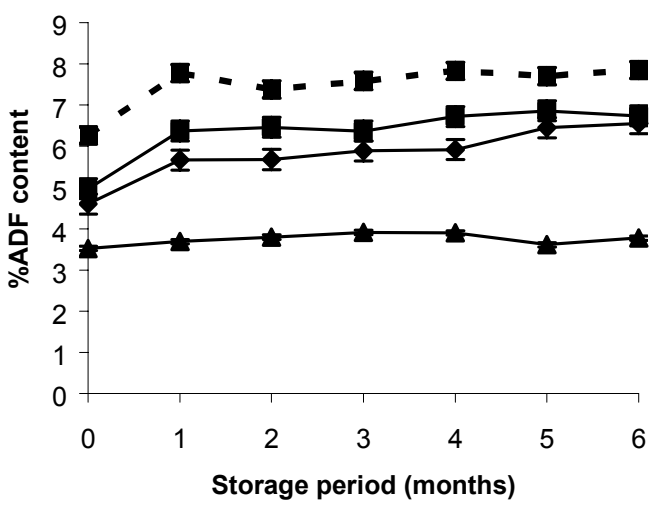

(b)

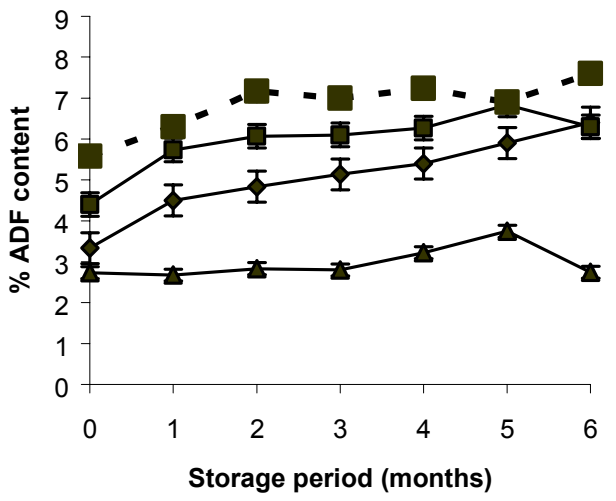

(d)

The lignin content for the four bean varieties after storage for 6 months was between $0.2-2.8 \%$ (Figure 4 ). 
Figure 4: Changes in Lignin content with storage for the beans collected from Lira and stored in different containers. (a) Polypropylene bags, (b) earthenware, (c) plastic buckets, (d) sisal bags

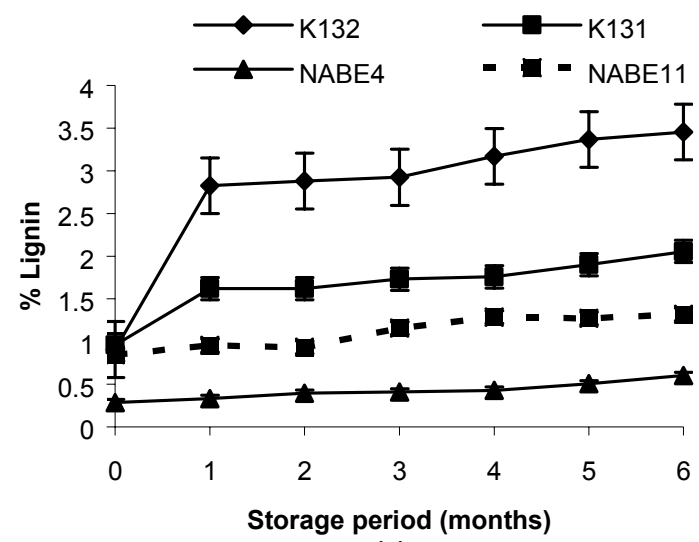

(a)

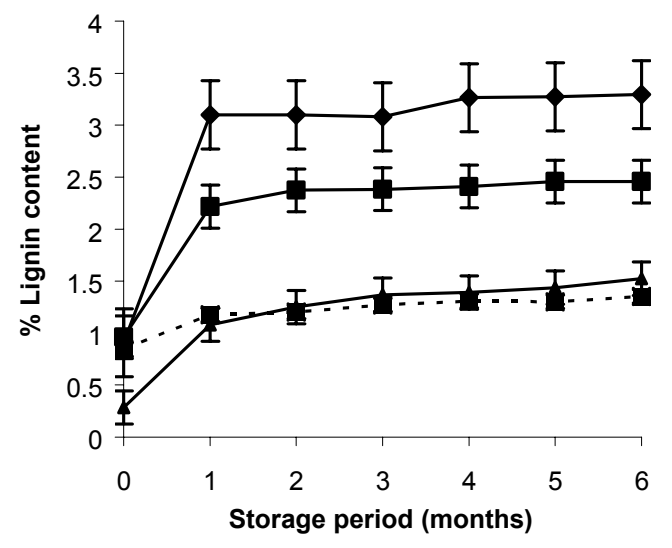

(c)

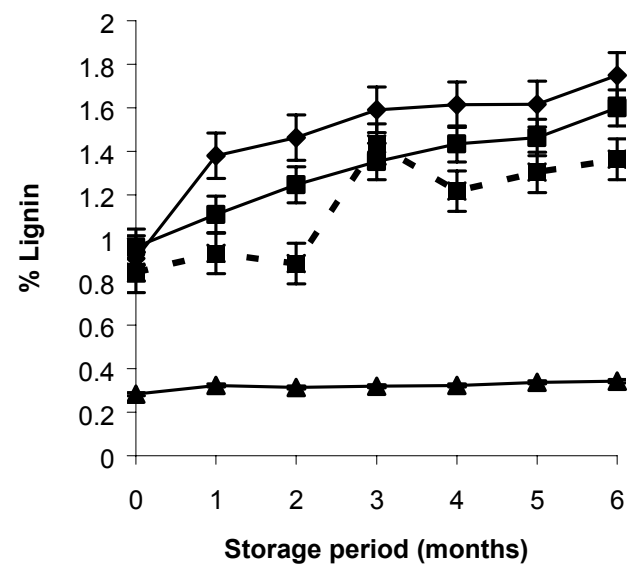

(b)

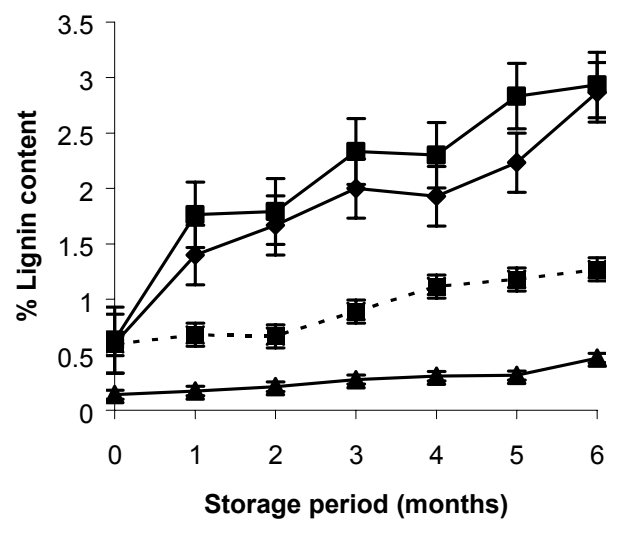

(d)

This is also in agreement with results reported by Bressani [9]. However, beans stored in plastic buckets had higher mean lignin accumulation followed by the samples stored in polypropylene bags, earthenware and sisal bags. Varieties with high cooking time (K131 and K132) had higher lignin levels (2.07 and 2.6\%, respectively) whereas varieties which had low cooking time (NABE4 and NABE11) had lower lignin levels ( 0.63 and $1.03 \%$, respectively). There was a strong positive correlation between lignin content and cooking time $\left(\mathrm{r}^{2}=0.72\right)$. This suggests that HTC defect entails lignification. 


\section{Influence of moisture content on bean hardening during storage}

The extent of bean hardening increased with increase in initial moisture content among the 4 varieties of beans studied (Table 3 ). The increase in cooking time was most pronounced in K131 and K132 varieties. Storage containers influenced the changes in cooking time for beans samples stored with different initial moisture content. It was observed that beans stored in containers (sisal bags) which allowed free movement of air registered lower increase in cooking time than those stored in plastic buckets, pots and polypropylene. In all containers the extent of development of HTC increased with the initial storage moisture of the beans.

\section{DISCUSSION}

The result of accelerated bean hardening study suggests that, development of HTC defect is variety and location dependent. Generally, variety K131 from Lira tended to exhibit higher cooking time than samples from Kabale and Namulonge. According to Stambolie [10], HTC development in common beans is influenced mainly by two environmental conditions during growth, namely the soil mineral composition and the amount of rainfall in a particular area. Presence of high levels of $\mathrm{Ca}$ and $\mathrm{Mg}$ contribute to the formation of insoluble pectates in the intercellular spaces of the cotyledon which hinder rapid movement of water in the seed during cooking or soaking. This leads to long cooking time [10]. On the other hand heavy rainfall results in the formation of a thin seed coat which allows faster movement of water across the seed coat during cooking hence short cooking time [10]. Varietal differences in HTC defect development, could not however be explained by differences in $\mathrm{Ca}$ and $\mathrm{Mg}$ content. The varietal differences seemed to be more related to the size of the bean grain, with the variety with small seeds exhibiting higher HTC development. Small seeded beans tend to lose moisture faster than bigger ones resulting in concentration of bean hardening enzymes (phytases and poly-methyl esterases) which accelerates liginification of the beans [11]. Although the cooking time increased in all samples stored under the 4 storage conditions, samples stored in earthenware showed relatively higher increase in cooking time with storage than samples stored in polypropylene, sisal bags and plastic buckets. The cooking time for samples of the K132 variety stored in plastic buckets increased sharply in the first month of storage. However, for other varieties in the same container, the increase was lower. The higher cooking time observed in samples stored in earthen ware could be attributed to the high relative humidity (93\%) which was observed during storage. High relative humidity is known to favor bean hardening. Furthermore, proneness to HTC is a function of variety and storage conditions [12]. Therefore, higher increase in cooking time for beans stored in plastic buckets in comparison to beans stored in polypropylene bags can be attributed to higher temperature $\left(27.9^{\circ} \mathrm{C}\right)$ and relative humidity $(84 \%)$ observed in the plastic bucket. The low cooking time for NABE1 1 and NABE4 samples stored in earthen ware and plastic buckets could be due to high water uptake caused probably by the large seed size of these varieties [13]. K132 stored in earthenware showed lower cooking time than other varieties probably because of the reduced temperature $\left(22^{\circ} \mathrm{C}\right)$ observed in the earthenware. Therefore, temperature is a major factor in the hardening of bean variety $\mathrm{K} 132$.

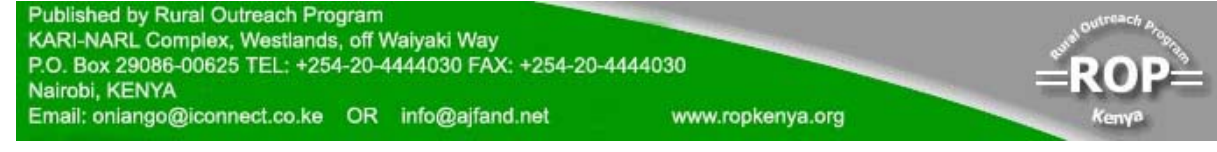


The higher ADF values observed in beans stored in plastic buckets could probably be attributed to the high temperature observed in the buckets $\left(27.9^{\circ} \mathrm{C}\right)$ compared to $22^{\circ} \mathrm{C}$, $23^{\circ} \mathrm{C}$ and $25.8^{\circ} \mathrm{C}$ recorded in earthenware, sisal and polypropylene bags, respectively. Since high ADF levels were observed in beans stored in containers which allowed increase in temperature, it probably suggests that temperature influences the increase in ADF content more than any other factors.

Lignification of the middle lamella occurs in beans stored for more than four months at elevated temperatures [14]. Furthermore, high lignin content of legume seed coat is related to poor cooking quality in beans [15]. Beans with seed coats having more than $1.9 \%$ lignin were poor in terms of cooking quality characteristics [16]. Therefore, K131 and K132 varieties can be rated low cooking quality beans after a six months storage period because their lignin content was above the $1.9 \%$ level. The lignin and cellulose content of the seed coat, and possibly of cotyledon cell walls, are important parameters influencing cooking quality of beans [17]. Furthermore, ADF and lignin content increased with storage, suggesting that, HTC development influences the levels of ADF and lignin.

Moisture plays a very big role in preserving the quality of beans and the quality of beans can be maintained by reducing the moisture content or the water activity [18]. High moisture content and relative humidity also stimulate phytase and pectin methyl esterase activity (PME) [19]. The phytase liberates Mg from phytic acid and PME hydrolyses pectin to pectinic acid and methanol. The pectinic acid combines with $\mathrm{Mg}$ forming magnesium pectate which cements cells together resulting in extended cooking time. This probably further explains higher hardening of beans observed in samples stored in the earthenware which tended to reduce the storage temperature.

\section{CONCLUSION}

Bean varieties grown in Uganda vary in the susceptibility to development of HTC defect. This defect also varies with growth location. The susceptibility was highest in small seed varieties (K131 and K132) and lowest in larger varieties (NABE4 and NABE11). The development of HTC defect is influenced by the moisture content of the beans and type of the storage containers. Beans stored at high moisture content were more affected than those stored at low moisture content. Storage containers (like sisal bags) which allow moisture equilibration with the environment and prevent heat build up retard HTC defect development more effectively. The development of HTC defect is associated with chemical changes like increase in lignin and acid detergent fibre. Therefore, it can be concluded that reduced moisture content and containers which prevent moisture and heat build up help in reducing HTC development in common beans during storage. 


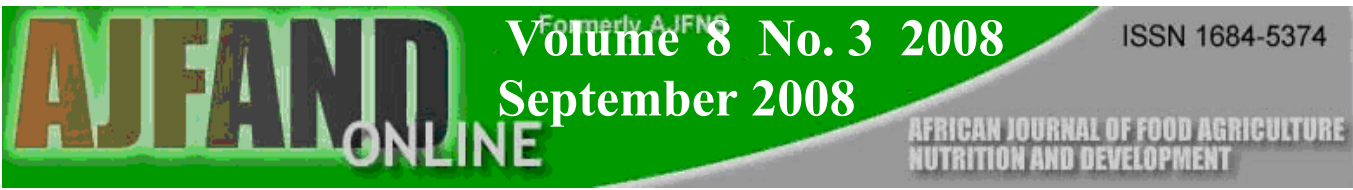

Table 1: Percentage hardening for beans stored in different storage containers

\begin{tabular}{lcccc}
\hline Container & Pots & Plastic buckets & Sisal bags & Polypropylene bags \\
\hline Variety & & $69^{\mathrm{b} 2}$ & $53^{\mathrm{a} 4}$ & $58^{\mathrm{b} 3}$ \\
\hline K132 & $70^{\mathrm{b} 1}$ & $70^{\mathrm{a} 2}$ & $53^{\mathrm{a} 4}$ & $65^{\mathrm{a} 3}$ \\
K131 & $77^{\mathrm{a} 1}$ & $53^{\mathrm{d} 2}$ & $42^{\mathrm{c} 4}$ & $43^{\mathrm{d} 3}$ \\
NABE4 & $58^{\mathrm{d} 1}$ & $60^{\mathrm{c} 2}$ & $45^{\mathrm{b} 4}$ & $55^{\mathrm{c} 3}$ \\
NABE11 & $68^{\mathrm{c} 1}$ & & & \\
\hline
\end{tabular}

Means in same column with different letter superscripts are significantly different $(p<0.05)$

Means in same row with different number superscripts are significantly different $(p<0.05)$ 


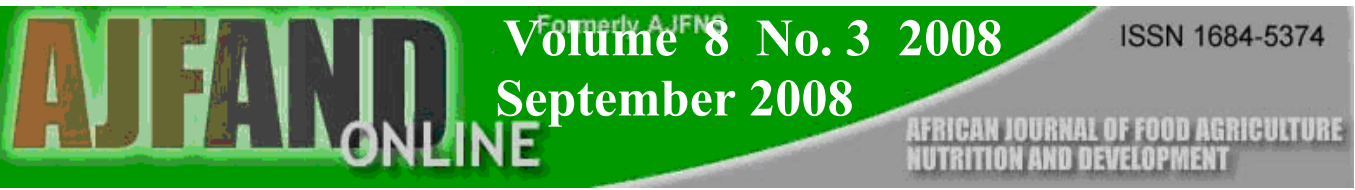

Table 2a: Ca content $(\mathrm{mg} / \mathrm{100g})$ of bean varieties grown in different agroecological zones

\begin{tabular}{|c|c|c|c|}
\hline Variety & NAARI & KABALE & LIRA \\
\hline K132 & $0.17^{\mathrm{a} 2}$ & $0.15^{\mathrm{a} 2}$ & $0.21^{11}$ \\
\hline K131 & $0.19^{\mathrm{a} 1}$ & $0.14^{\mathrm{a} 2}$ & $0.16^{\mathrm{a} 2}$ \\
\hline NABE4 & $0.17^{\mathrm{a} 2}$ & $0.13^{\mathrm{a} 3}$ & $0.22^{\mathrm{b} 1}$ \\
\hline NABE11 & $0.33^{\mathrm{b} 1}$ & $0.17^{\mathrm{a} 3}$ & $0.21^{\mathrm{b} 2}$ \\
\hline
\end{tabular}

Table 2b: Mg content $(\mathrm{mg} / 100 \mathrm{~g})$ of bean varieties grown in different agroecological zones

\begin{tabular}{|c|c|c|c|}
\hline Variety & NAARI & KABALE & LIRA \\
\hline K132 & $0.19^{b 1}$ & $0.18^{\mathrm{a} 1}$ & $0.23^{\mathrm{b2}}$ \\
\hline K131 & $0.21^{\mathrm{b} 2}$ & $0.15^{\mathrm{a} 1}$ & $0.16^{a 1}$ \\
\hline NABE4 & $0.11^{\mathrm{a} 1}$ & $0.09^{\mathrm{a} 1}$ & $0.13^{a^{1}}$ \\
\hline NABE11 & $0.24^{\mathrm{d} 2}$ & $0.13^{\mathrm{a} 1}$ & $0.17^{a^{1}}$ \\
\hline
\end{tabular}


Table 3: The percentage increase in cooking time for beans stored at different moisture content for a period of 6 months

\begin{tabular}{|c|c|c|c|c|c|c|c|c|c|c|c|c|c|}
\hline \multicolumn{2}{|c|}{ Container } & \multicolumn{3}{|c|}{ Pots } & \multicolumn{3}{|c|}{ Plastic buckets } & \multicolumn{3}{|c|}{ Sisal bags } & \multicolumn{3}{|c|}{ Polypropylene } \\
\hline \multicolumn{2}{|c|}{$\mathrm{M} / \mathrm{C}(\%)$} & 9 & 12 & 15 & 9 & 12 & 15 & 9 & 12 & 15 & 9 & 12 & 15 \\
\hline Variety & IC & & & & & & & & & & & & \\
\hline K132 & $18^{\mathrm{a} 12}$ & $65^{\mathrm{a} 6}$ & $75^{\mathrm{a} 5}$ & $79^{\mathrm{a} 4}$ & $81^{\mathrm{a} 3}$ & $84^{\mathrm{a} 2}$ & $92 \mathrm{a}^{1}$ & $25^{\mathrm{b} 11}$ & $48^{\mathrm{a} 9}$ & $40^{\mathrm{c} 10}$ & $62^{\mathrm{b} 7}$ & $52^{\mathrm{b} 8}$ & $53^{\mathrm{c} 7}$ \\
\hline K131 & $20^{\mathrm{b} 11}$ & $35^{\mathrm{c} 9}$ & $55^{\mathrm{c} 7}$ & $58^{\mathrm{c} 6}$ & $74^{\mathrm{b} 2}$ & $75^{\mathrm{b} 2}$ & $79^{\mathrm{b} 1}$ & $30^{\mathrm{a} 10}$ & $46^{\mathrm{b} 8}$ & $48^{\mathrm{a} 8}$ & $66^{\mathrm{a} 3}$ & $62^{\mathrm{a} 5}$ & $63^{\mathrm{b4}}$ \\
\hline NABE4 & $15^{\mathrm{c} 11}$ & $64^{\mathrm{a} 2}$ & $63^{\mathrm{b} 2}$ & $40^{\mathrm{d} 4}$ & $33^{\mathrm{d} 7}$ & $34^{\mathrm{d} 5}$ & $72^{\mathrm{c} 1}$ & $17^{\mathrm{c} 10}$ & $18^{\mathrm{d} 9}$ & $43^{b 3}$ & $37^{\mathrm{c} 6}$ & $26^{\mathrm{d} 8}$ & $66^{\mathrm{a} 2}$ \\
\hline NABE11 & $15^{\mathrm{c} 8}$ & $48^{\mathrm{b} 4}$ & $52^{\mathrm{d} 4}$ & $72^{\mathrm{b} 1}$ & $44^{\mathrm{c} 5}$ & $57^{\mathrm{c} 3}$ & $60^{\mathrm{d} 2}$ & $30^{\mathrm{a} 7}$ & $34^{\mathrm{c} 6}$ & $45^{\mathrm{b} 5}$ & $33^{\mathrm{d} 6}$ & $47^{\mathrm{c} 5}$ & $50^{\mathrm{d} 4}$ \\
\hline
\end{tabular}

IC- cooking time before storage, $M C$ - moisture content

Means in same column with different letter superscripts are significantly different $(p<0.05)$

Means in same row with different number superscripts are significantly different $(p<0.05)$ 


\section{REFERENCES}

1. FAO. United Nations Food and Agriculture Organisation, Statistical Databases FAO, Rome, 2004.

2. Gridley HE Breeding-pathology interface in the improvement of beans. CIAT African Workshop Series 1992: 23, 85.

3. Opio F and S Male-Kayiwa The status of bean breeding in Uganda. Breeding for disease resistance with emphasis on durability. Proceedings of Regional workshop for eastern, central, and southern Africa. Daniel, D. L., (Ed). Ministry for Development Cooperation (DGIS), Netherlands. 1994: 110-113.

4. FAO. United Nations Food and Agriculture Organisation, Statistical Databases FAO, Rome, 2005.

5. TM Shiga, Lajolo FM and CC FilisettiChanges in the cell wall polysaccharides during storage and hardening of beans Food Chem. 2004: 84, $53-64$

6. CIAT. Bean improvement for the tropics, summary annual report. 2004.

7. Mattson S The cookability of yellow peas, J. of Agric. 1946: 11, 185-196

8. AOAC. Official methods of analysis ( $17^{\text {th }}$ Edition) Washington DC, USA: 1999 Association of Official Analytical Chemists.

9. Bressani R Overview on bean grain quality. Latin American Society of Nutrition, 1989: 39, 419-425.

10. Stambolie M, George D, Tsuetanova $\mathbf{K}$ and YT Tohu Effects of some agro technical ago-climatic factors on the technological quality of Phaseolus vulgaris grown on calcareous chernozen. Rasternievedni Nank. 1995: 32, 65-67

11. Stanley DW, Michaels TE, Plhak LC and BK Caldwell Storage-induced hardening in 20 common bean cultivars. J. Fd. Qual. 1990: 13, 233-247.

12. Giselle AM, Banu FO, Lisa JM and SS Nielsen Analysis of Hard-to-Cook Red and Black Common Beans Using Fourier Transform Infrared Spectroscopy J. Agric. Food Chem. 2004: 52, $1470-1477$

13. Reyes-Moreno C, Rouzaud-Sandez O , Milán-Carrillo J, Garzón-Tiznado JA and L Camacho-Hernández Hard-to-cook tendency of chickpea (Cicer arietinum L) varieties. J.FSci. 2001: 8, 1002-1012 
14. Shomer I, Paster $\mathbf{H}$, Linder $\mathbf{P}$ and $\mathbf{R}$ Vasiliver The role of cell wall structure in the hard-to cook phenomenon in beans (Phaseolus vulgaris L). Food Str. 1990: 9, 139-149

15. Rodriguez FM and EMT Mendoza Physicochemical basis for hard seeds in mung bean (Vigna radiata L Wilezek). J. Agric. Food. Chem. 1990: 38, 29 -33.

16. Mafuleka MM, Ott DB, Hosfield GL and MA Uebersax The role of phytase and lignin in decorticated dry beans (Phaseolus vulgaris) hardening during storage. J. Food Proc \& Pres. 1993: 17, 1-20.

17. Muller FM. Cooking quality of pulses. J. Sci Fd Agric. 1969: 18, 292-295

18. Paredes- Lopez O, Barradas I and C Reyes-Moreno. Prediction of the effect of storage conditions on water content and activity of common beans. J. F Sci. 1989: 54, 1373-1375.

19. Jones PMB and D Boulter The cause of reduced cooking rate in Phaseolus vulgaris following adverse storage conditions. J.F Sci. 1983: 48, 623-649 